\title{
KRONIKA
}

\section{DOKTORAT MARII SZAFRANIEC}

W dniu 16 czerwca 2004 roku, w sali Rady Wydziału Prawa i Administracji w Collegium Novum Uniwersytetu Jagiellońskiego w Krakowie, odbyła się publiczna obrona rozprawy doktorskiej mgr Marii Szafraniec pt. Przekroczenie granic obrony koniecznej motywowane strachem bądź wzburzeniem. Promotorem w przewodzie był prof. dr hab. Zbigniew Ćwiąkalski. Warto zaznaczyć, iż mgr Maria Szafraniec była pierwszym wypromowanym przez Profesora doktorem. Obrona odbyła się przed specjalnie w tym celu powołaną Komisją (piętnastu profesorów WPiA UJ), pod przewodnictwem prof. dr hab. Józefa Wójcikiewicza, Prodziekana WPiA UJ.

Impulsem do podjęcia przez Doktorantkę tematu swojej rozprawy było wprowadzenie w Kodeksie karnym z 1997 r. swoistego novum, jakim jest obligatoryjne odstąpienie od wymierzenia kary w przypadku przekroczenia granic obrony koniecznej, jeżeli było to wynikiem strachu lub wzburzenia usprawiedliwionego okolicznościami.

Autoreferat Doktorantki koncentrował się zasadniczo wokół problematyki stanu psychicznego i emocjonalnego osoby broniącej się w warunkach zagrożenia, jak również wpływu tego stanu na sposób zachowania.

Recenzenci - prof. dr hab. Maria Szewczyk (WPiA UJ) oraz prof. dr hab. Andrzej J. Szwarc (WPiA UAM) - wysoko ocenili przedłożoną im pracę. W szczególności podkreślili niezwykłą skrupulatność i staranność dokumentacji oraz pełne wykorzystanie dorobku doktryny polskiej i częściowo zagranicznej (w tym literatury psychiatrycznej). 
Pytania, jakie zostały skierowane do Doktorantki, koncentrowały się głównie wokół zagadnienia samoistności obrony koniecznej, a także możliwości podjęcia obrony koniecznej wobec działania funkcjonariuszy publicznych. W dyskusji głos zabrali m.in. profesorowie Andrzej Zoll, Zbigniew Hołda, Piotr Kardas.

W tajnym głosowaniu Komisja jednomyślnie podjęła decyzję o skierowaniu do Rady Wydziału Prawa i Administracji UJ wniosku o nadanie stopnia naukowego doktora nauk prawnych. Tego samego dnia Rada Wydziału Prawa i Administracji UJ w tajnym głosowaniu podjęła uchwałę o nadaniu mgr Marii Szafraniec stopnia naukowego doktora nauk prawnych.

Anna Górecka*

* Uniwersytet Kardynala Stefana Wyszyńskiego. 